\title{
Changements des comportements alimentaires au Vietnam : L'exotique n'est pas encore quotidien
}

\section{Nelly Krowolski}

\section{(2) OpenEdition \\ 12 Journals}

Édition électronique

URL : https://journals.openedition.org/tc/386

DOI : $10.4000 /$ tc.386

ISSN : 1952-420X

Éditeur

Éditions de l'EHESS

\section{Édition imprimée}

Date de publication : 1 avril 1999

ISSN : 0248-6016

\section{Référence électronique}

Nelly Krowolski, « Changements des comportements alimentaires au Vietnam : L'exotique n'est pas encore quotidien », Techniques \& Culture [En ligne], 31-32 | 1999, mis en ligne le 26 octobre 2005, consulté le 29 septembre 2022. URL : http://journals.openedition.org/tc/386 ; DOI : https://doi.org/ $10.4000 /$ tc. 386

Ce document a été généré automatiquement le 29 septembre 2022.

Tous droits réservés 
Changements des comportements alimentaires au Vietnam :

L'exotique n'est pas encore quotidien

Nelly Krowolski 